Karataş, K., Aslan, H. ve Başcillar, M. (2019). Hopelessness and Satisfaction With Life Among Disabled Veterans. Toplum ve Sosyal Hizmet, 30(1), 1-18.

Research

Makale Geliş Tarihi:06.09.2018

Makale Kabul Tarihi: 13.12.2018

\title{
HOPELESSNESS AND SATISFACTION WITH LIFE AMONG DISABLED VETERANS
}

\section{Malul Gazilerin Umutsuzluk ve Yaşam Doyumu}

\author{
Kasım KARATAŞ* \\ Harun ASLAN** \\ Mehmet BAŞCILLAR ${ }^{* * *}$ \\ * Prof. Dr., Hacettepe Üniversitesi İktisadi İdari Bilimler Fakültesi, Sosyal Hizmet Bölümü, \\ ORCID ID: 0000-0002-4817-9981
}

${ }^{* *}$ Arş. Gör., Hacettepe Üniversitesi İktisadi İdari Bilimler Fakültesi, Sosyal Hizmet Bölümü, ORCID ID: 0000-0001-9830-1765

*** Öğr. Gör., İstanbul Gelişim Üniversitesi Sağlık Bilimleri Yüksekokulu, Sosyal Hizmet(İngilizce) Bölümü, ORCID ID: 0000-0002-0223-8050

\begin{abstract}
The aim of this study is to examine the relationship between life satisfaction and hopelessness of disabled veterans and to determine whether the dimensions of hopelessness in explaining their life satisfaction in terms of socio-demographic and professional variables of disabled veterans have a meaningful effect. Satisfaction with Life (5 items) and Beck Hopelessness (20 items) were used as scales in this study. The sample of this study is 159 disabled veterans among the disabled veterans living in Turkey. All of the disabled veterans in this study are male and their mean age is $40.79 \pm 6.84$ (mean \pm standard deviation). Considering correlation between all sub-scales of Beck Hopelessness, there was a significant correlation between feelings and expectations about the future domain and loss of motivation domain and also there was strong correlation with hope domain. The findings illustrate that there is a significant relationship between life satisfaction and hopelessness in disabled veterans.
\end{abstract}

Keywords: Disabled veterans, satisfaction with life, hopelessness 


\section{ÖZET}

Bu çalışmanın amacı Türkiye'deki malul gazilerin yaşam doyumu ile umutsuzluk boyutları arasındaki ilişkileri incelemek ve malul gazilerin hem sosyo-demografik hem de mesleki bilgileri doğrultusunda onların yaşam doyumunu açıklamada umutsuzluğun boyutlarının anlamı bir etkiye sahip olup olmadığını ortaya koymaktır. Çalışmada yaşam doyumunu ölçmek için beş maddeden oluşan yaşam doyumu ölçeği ve umutsuzluğu ölçmek için Beck ve ark. (1974) tarafından geliştirilen ve yirmi maddeden oluşan umutsuzluk ölçeğinden yararlanılmıştır. Çalışmanın örneklemi Türkiye'de yaşayan malul gaziler içerisinden 159 malul gazi oluşturmaktadır. Çalışmaya katılan malul gazilerin tamamı erkek olup yaş

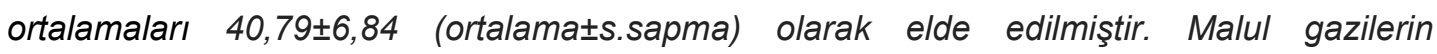
umutsuzluk düzeylerini açıklamada umutsuzluk ölçeğinin geleceğe yönelik duygu ve beklentiler, motivasyon kaybı ile umut boyutları ayrıca ele alınmıştır. Aynı zamanda yaşam doyumu ile umutsuzluk arasında da anlamı bir ilişki olduğu tespit edilmiştir.

Anahtar Kelimeler: Malul gazi, yaşam doyumu, umutsuzluk

\section{INTRODUCTION}

Disabled veterans are a wide and heterogeneous group who dedicated their life to serve for the nation and have incurred service related injuries, which cause loss of specific physical or psychological functions. The exact number of disabled veterans in the world isn't known; but, in USA there were approximately 4 million disabled veterans in 2016. Approximately 1.2 million of them have 70 percent or higher disability degree (U.S. Census Bureau, 2016). On the other hand, according to the official figures in 2012, the number of disabled veterans in Turkey, was approximately 4 thousand (TBMM, 2012).

Disability leads to major changes and devastating effects in the life of disabled veterans. In this context, post military lives of disabled veterans are identified with some challenges, which cause disabled veterans to have increased dependency to their families for socio-economic support and daily care. At the same time, they may experience physical, mental and social problems in their new lives (Foote, Mac Kinnon, Robbins, Pessagno, \& Portner, 2015; Kocalevent et al., 2016; Wu \& Lewis, 2015). Hence their attitudes and feelings toward the future may differ.

The disabled veterans confronts the individual with a multitude of evolving physical and psychosocial challenges such as impairments in physical functioning, prosthesis 
use, pain, changes in family/peer relations, changes in employment status or occupation, and alterations in body image and self-concept. Such stressors challenge the individual's ability to maintain emotional well-being and may engender maladaptive reactions that lead to poor psychosocial adaptation (Tuncay \& Musabak, 2015).

The change that disabled veterans live both physically and mentally may affect their satisfaction with life and hopelessness levels. Satisfaction with life express to wellbeing and positive emotions in daily affairs in terms of happiness and morale (Vara, 1999). Also satisfaction with life is a component of subjective well-being that consists of a cognitive assessment of a person's whole life (Diener, Emmons, Larsen, \& Griffin, 1985). Satisfaction with life is related to many factors such as age, gender, working and working conditions, economic level, family life, religion, personality, social conditions, biological and health status (Köker, 1991). These factors can directly affect disabled veterans' lives.

On the other side, disabled veterans may have negative expectations about the future and this can be defined as hopelessness in general terms. Moreover, hopelessness is a cognitive disorder that is perceived by the person according to the expectations and circumstances that may be caused by future negative consequences (Beck, Weissman, Lester, \& Trexler, 1974). It is emphasized that hopelessness is the main factor in depression, and that the concepts accompanying despair are helplessness, pessimism, lack of actuation, inability to work and feelings of guilt (Melges \& Bowlby, 1969). Hopelessness includes negative thoughts and failures. Beck et al. (1974) describe three aspects of hopelessness: Feelings about the future, loss of motivation, future expectations. Feelings about the future revolved around affectively toned associations such as hope and enthusiasm; happiness; faith; and good times. Loss of motivation is concerned with giving up: deciding not to want anything; and not trying to get something that is wanted. Future expectations includes anticipations regarding what life will be like: a dark future; getting good things; things not working out; and the future being vague and uncertain.

The researches which in terms of psycho-social perspective for disabled veterans in Turkey is extremely limited. In the lives of disabled veterans after returning home, they may face many problems which are physical, mental and social. Therefore, it makes this research more important for the hopelessness and life satisfaction of disabled veterans. 
In this study, it is aimed to examine hopelessness and satisfaction with life of disabled veterans. In this context, the relationship between hopelessness in terms of its sub-dimensions for disabled veterans and disabled veterans' satisfaction with life is discussed. The effect of socio-demographic variables on hopelessness and satisfaction with life are also being examined.

\section{METHODS}

In this research descriptive model and relational model were used. Descriptive research model has a feature to identify the current situation of the research carried out and has the ability to represent the truth (Ural \& Kılıç, 2005). The purpose of descriptive research is to describe the characteristics of the people involved in the research (Büyüköztürk, 2013). In the study, demographic characteristics of the participants were examined descriptively. Relationally, it is examined whether there is a relationship between demographic variables and the satisfaction with life and hopelessness of the disabled veterans.

\section{Participants and Procedures}

The population of the research is the disabled veterans in Turkey. The official number of disabled veterans in Turkey, in 2012, was approximately 4 thousands (TBMM, 2012). There isn't any open accessed database that gives information about disabled veterans in Turkey. For that reason one of the non-probability sampling method 'convenience sampling' was used.

The scope of this research is disabled veterans. The researchers were contacted by the manager of a website followed by the disabled veterans and the relatives of martyrs. Information about the research was announced on the website. Veterans were asked to send the contact information to the researcher via internet. As a result of this announcement, the contact information of the 212 disabled veterans gathered. Then, each veteran was contacted via telephone and informed about the research. Questionnaires were sent to the disabled veterans who are volunteer to participate this research. 172 disabled veterans filled the questionnaire.13 participants were excluded from the scope of the study because of incomplete answers. As a result, the responses of 159 participants were evaluated. 


\section{Instruments}

An interview form and two scales were used in this study. The interview form created by researchers (18 items) consists of two sections. In the first section, questions about socio-demographic variables; in the second section, questions about professional information were asked. Satisfaction with Life (Diener et al., 1985) (5 items) and Beck Hopelessness (Beck et al. 1974) (20 items) were used as scales in this study.

Satisfaction with Life Scale was developed by Diener et al. (1985). This scale, developed to measure life satisfaction, which consists of 5 items and a rating system of seven includes statements ranging from "1=Strongly Disagree" to "7=Strongly Agree". The scores obtained from each item can vary from 1 to 7 , and the total score can range from 1-35. High scores indicate that life satisfaction is better. Turkish adaptation of the scale was carried out by Köker (1991). The study was conducted on a sample of 150 people (17-21 years) and it was concluded that there was a sufficient relationship between the scores obtained from each item. Testretest reliability was obtained .85 (Köker, 1991). In our study, internal consistency of the scale was .97 .

The Beck-Hopelessness Scale was developed by Beck et al. (1974). The scale consists of statements about the individuals' negative expectations about the future. This scale covers three domains. These are feelings about the future (5 items), loss of motivation ( 8 items), and future expectations (7 items). Totally BeckHopelessness Scale consists of 20 items and has two response options for each item " $1=$ Yes" or "2=No". Turkish adaptation of the scale was first carried out by Seber (1991) and Cronbach's alpha coefficient was found .82 .

Later on, another adaptation was carried out by Durak (1994) and Cronbach's alpha coefficient was found .85. In Turkish adaption, a group of questions did not correlated with any domains and those questions constituted an independent factor in the factor analysis. Consequently, a new sub-scale as "hope domain" for Turkish society was created by (Durak, 1994). On the other hand, feelings about the future and future expectations domains are unified. The internal consistency of the three sub-scales for assessing hopelessness, the following Cronbach's alfas were found: feelings and expectations about the future .78, loss of motivation .72 , hope .72 (Durak, 1994). In our study, Cronbach's alpha coefficient of the scale was .91 and 
internal consistency of the sub-scales was found: feelings and expectations about the future .83 , loss of motivation .75 , hope .81 .

\section{Data Collection Procedure}

The data of this research were gathered through web-site which is frequently visited by disabled veterans. We contacted with manager of the web site, visited frequently by disabled veterans. Online research forms were loaded on this web site. Before filling the form, purpose of the study was summarized and stated that data would be anonymous and participants were asked to fill the questionnaire package after giving informed written consent by clicking the related link.

\section{Statistical Analyses}

SPSS 23 was used for the data analysis and the study has a confidence level of $95 \%$. Descriptive analysis was performed for all variables. As a result of test of normality, results showed that it was appropriate for parametric tests. In order to evaluate the correlation between Satisfaction with Life and sub-scales of Beck Hopelessness scale, Pearson correlation was used. Furthermore, $t$ - test and an analysis of variance (ANOVA) were used in order to compare scale results with regard to socio-demographic and professional variables. Regarding the differential effects of measures on sub-scales, a hierarchical model was created. Feelings and expectations about the future domain and hope domain were entered in Step-1 and loss of motivation domain were entered in Step-2. No concerns regarding multicollinearity were identified.

\section{FINDINGS}

\section{Descriptive analyses}

In Table 1, socio-demographic variables of participants are presented. In this study, all of the participants were male and $93.1 \%$ of the participants were married. Table 1 also shows that $13.2 \%$ of the participants were primary school graduates (5 yeareducation); 13.8\% were secondary school graduates (8 year-education); 43.4\% were graduates of high school (12 year-education); and equivalent; $25.2 \%$ of the participants had a bachelor's degree; $4.4 \%$ of the participants had a postgraduate degree. 
As for the distribution by age in this study, it is seen that data were collected from middle aged and older individuals. According to Table 1,40.9\% of the individuals are 40 years old and under the age of 40 , and $59.1 \%$ of them were 41 years old and over. The average age was $40.79 \pm 6.84$. The median and mode ages were 42 and 41. In accordance with Levinson's theory, middle age period comprise between 4065 years old (Levinson, 1978). For this reason, it was looked at before and after the age of 40 , which limits the period of first adulthood and middle adulthood.

Table 1. Socio-demographic variables $(\mathrm{N}=159)$

\begin{tabular}{|c|c|c|}
\hline & $\mathbf{N}$ & $\%$ \\
\hline \multicolumn{3}{|l|}{ Gender } \\
\hline Male & 159 & 100.0 \\
\hline \multicolumn{3}{|l|}{ Age } \\
\hline 40 and below & 65 & 40.9 \\
\hline 41 and above & 94 & 59.1 \\
\hline Mean \pm sd & \multicolumn{2}{|c|}{$40.79 \pm 6.84$} \\
\hline Median age & \multicolumn{2}{|c|}{42} \\
\hline Mode & \multicolumn{2}{|c|}{41} \\
\hline Lowest - highest data & \multicolumn{2}{|c|}{$24-58$} \\
\hline \multicolumn{3}{|l|}{ Education } \\
\hline Primary school graduate & 21 & 13.2 \\
\hline Secondary school graduate & 22 & 13.8 \\
\hline High school graduate or equivalent & 69 & 43.4 \\
\hline Bachelor's degree & 40 & 25.2 \\
\hline Postgraduate degree & 7 & 4.4 \\
\hline \multicolumn{3}{|l|}{ Marital status } \\
\hline Single/widow & 11 & 6.9 \\
\hline Married & 148 & 93.1 \\
\hline \multicolumn{3}{|l|}{ Family type } \\
\hline Nuclear family & 124 & 78.0 \\
\hline Extended family & 35 & 22.0 \\
\hline \multicolumn{3}{|l|}{ Number of children } \\
\hline No children & 22 & 13.8 \\
\hline 1 & 88 & 55.3 \\
\hline 2 and more & 49 & 30.8 \\
\hline \multicolumn{3}{|l|}{ Income } \\
\hline 2000 TL and below & 16 & 10.0 \\
\hline 2001-3000 TL & 46 & 28.9 \\
\hline 3001-4000 TL & 37 & 23.3 \\
\hline 4001-5000 TL & 41 & 25.8 \\
\hline $5001 \mathrm{TL}$ and above & 19 & 11.9 \\
\hline \multicolumn{3}{|l|}{ Residence } \\
\hline Owner & 90 & 56.6 \\
\hline Tenant & 35 & 22.0 \\
\hline Public House & 8 & 5.0 \\
\hline Parent's House & 26 & 16.4 \\
\hline \multicolumn{3}{|l|}{ Car ownership } \\
\hline Yes & 109 & 68.6 \\
\hline No & 50 & 31.4 \\
\hline
\end{tabular}




$\begin{array}{lcc}\text { Yes } & 85 & 53.5 \\ \text { No } & 74 & 46.5 \\ \text { Alcohol use } & 54 & 34.0 \\ \text { Yes } & 105 & 66.0 \\ \text { No } & & \\ \text { Frequency of alcohol use (N=54) } & 2 & 3.7 \\ \text { Everyday } & 6 & 11.1 \\ \text { Two or three times a week } & 8 & 14.8 \\ \text { Once a week } & 13 & 24.1 \\ \text { Once a month } & 25 & 46.3 \\ \text { Once a year } & \end{array}$

Significant number of participants were working at a new job. But in contrast, sample of this research were mostly middle and low income people. According to data showed in Table 1, 10\% of the participants had income less than $2000 \mathrm{TL}, 28.9 \%$ between 2001-3000 TL, 23.3\% between 3001-4000 TL, 25.8\% between 4001-5000 TL and only $11.9 \%$ had income more than $5001 \mathrm{TL}$. In Turkey, minimum wage is 1603,12 TL (Turkish Statistical Institute, 2018). According to Confederation of Turkish Trade Unions, poverty line was 5492 TL and starvation line was $1686 \mathrm{TL}$ (Confederation of Turkish Trade Unions, 2018). 
Table 2. Professional variables $(\mathrm{N}=159)$

\begin{tabular}{lcc}
\hline & N & $\%$ \\
\hline Work unit & 89 & 56.0 \\
Land forces & 4 & 2.5 \\
Air forces & 3 & 1.9 \\
Naval forces & 46 & 28.9 \\
Gendarme & 17 & 10.7 \\
National police & & \\
Working period until being veteran (year) & 118 & 74.2 \\
5 years and below & 15 & 9.4 \\
6-9 years & 26 & 16.4 \\
10 years and above & & \\
Degree of disability & 4 & 2.5 \\
First degree & 8 & 5.0 \\
Second degree & 9 & 5.7 \\
Third degree & 19 & 11.9 \\
Fourth degree & 37 & 23.3 \\
Fifth degree & 82 & 51.6 \\
Sixth degree & & \\
Year of being a veteran & 10 & 6.3 \\
1985-1990 & 42 & 26.4 \\
1991-1995 & 51 & 32.1 \\
1996-2000 & 14 & 8.8 \\
2001-2005 & 24 & 15.1 \\
2006-2010 & 18 & 11.3 \\
2011-2015 & & \\
Current Working Status & 115 & 72.3 \\
Yes & 44 & 27.7 \\
No & & \\
Employment Field (N=115) & 67 & 56.6 \\
Public Sector & 48 & 22.0 \\
Private Sector & & \\
\hline
\end{tabular}

According to Table 2, a considerable part of participants worked in land forces. When the distribution of the working period until being veteran was considered, it is seen that $74.2 \%$ of the individuals were veterans for a period 5 years and below. When we look at the data on degree of disability of veterans, it is clearly seen that almost half of veterans were at the sixth degree of disability. The degree of disability which ranges from 1 to 6 is determined by the Social Security Institution in Turkey. As the level of disability increases, the degree of disability approaches to 1 at the most. 'Full blindness of two eyes', 'absence of both hands and all fingers' and 'absence of two legs' are examples for first degree disability. Full blindness of one eye' and 'losing leg or arms' are examples for second degree disability. 'Injury of the internal organs' and head injuries are some examples for third degree disability. 'Deafness' and 'mental problems that don't affect daily life to much' are some of the examples of fourth degree disability. 'Mental illnesses' is an example for fifth degree disability. 'Absence of head and index finger ' and 'difficulty of speaking' are 
examples of sixth degree disability (Republic of Turkey Council of Ministers, 1953). The disability degree is used to determine how much social benefit and social right disabled veterans will get.

\section{Comparative analyses}

In Table 3, it is seen that there is a correlation between satisfaction with life and each domain of Beck Hopelessness. There was a negatively strong correlation $(p<$ .01) between satisfactions with life and feelings and expectations about the future domain $(r=-.566 ; p<.01)$ and there was a negatively strong correlation $(p<.01)$ between satisfactions with life and loss of motivation domain $(r=-.536 ; p<.01)$. Lastly, satisfaction with life was negatively strong correlated with hope domain ( $r=-$ $.541 ; \mathrm{p}<.01)$.

Table 3. Pearson correlation between Satisfaction with Life and sub-scales of Beck Hopelessness

\begin{tabular}{|c|c|c|c|c|}
\hline & $\begin{array}{l}\text { Satisfaction with } \\
\text { life }\end{array}$ & $\begin{array}{l}\text { BHS Feelings and } \\
\text { expectations about } \\
\text { the future }\end{array}$ & $\begin{array}{l}\text { BHS Loss of } \\
\text { motivation }\end{array}$ & $\begin{array}{l}\text { BHS } \\
\text { Hope }\end{array}$ \\
\hline Satisfaction with Life & 1 & & & \\
\hline $\begin{array}{l}\text { BHS Feelings and } \\
\text { expectations about the } \\
\text { future }\end{array}$ & $-0.566^{\star \star}$ & 1 & & \\
\hline BHS Loss of motivation & $-0.536^{\star \star}$ & $0.759^{\star \star}$ & 1 & \\
\hline BHS Hope & $-0.541^{* *}$ & $0.796^{\star \star}$ & $0.704^{\star \star}$ & 1 \\
\hline
\end{tabular}

${ }^{* *} p<0,01,{ }^{*} p<0,05$

Considering correlation between all sub-scales of Beck Hopelessness, there was a positively strong correlation between feelings and expectations about the future domain and loss of motivation domain $(r=.759 ; p<.01)$ and also there was positively strong correlation with hope domain $(r=.796 ; p<.01)$. Moreover, there was a positively strong correlation between hope domain and loss of motivation domain $(r=$ $.704 ; p<.01)$. 
Table 4. Means, standard deviations, and independent sample $t$-tests $(t)$ ofSatisfaction with Life and Beck Hopelessness sub-scales of participants

\begin{tabular}{|c|c|c|c|c|c|c|c|c|}
\hline & \multicolumn{2}{|c|}{$\begin{array}{l}\text { Satisfaction } \\
\text { with life }\end{array}$} & \multicolumn{2}{|c|}{$\begin{array}{c}\text { BHS Feelings and } \\
\text { expectations about } \\
\text { the future }\end{array}$} & \multicolumn{2}{|c|}{$\begin{array}{l}\text { BHS Loss of } \\
\text { motivation }\end{array}$} & \multicolumn{2}{|c|}{ BHS Hope } \\
\hline & $M$ & $t$ & $M$ & $t$ & $M$ & $t$ & $M$ & $t$ \\
\hline \multicolumn{9}{|l|}{ Age } \\
\hline 40 and below & $\begin{array}{c}3.37 \\
(1.59)\end{array}$ & \multirow{2}{*}{$2.070^{\star}$} & $1.34(0.34)$ & \multirow{2}{*}{$-2.535^{\star}$} & $\begin{array}{c}1.39 \\
(0.25)\end{array}$ & \multirow{2}{*}{$3.297^{\star}$} & $\begin{array}{c}1.40 \\
(0.29)\end{array}$ & \multirow{2}{*}{-1.409} \\
\hline 41 and above & $\begin{array}{l}2.82 \\
(1.67)\end{array}$ & & $1.49(0.39)$ & & $\begin{array}{c}1.54 \\
(0.29)\end{array}$ & & $\begin{array}{l}1.47 \\
(0.34)\end{array}$ & \\
\hline \multicolumn{9}{|l|}{ Marital status } \\
\hline Single/ widow & $\begin{array}{c}2.56 \\
(1.54)\end{array}$ & \multirow{2}{*}{1.016} & $1.47(0.38)$ & \multirow{2}{*}{-0.374} & $\begin{array}{c}1.50 \\
(0.30)\end{array}$ & \multirow{2}{*}{-0.186} & $\begin{array}{c}1.32 \\
(0.29)\end{array}$ & \multirow{2}{*}{1.235} \\
\hline Married & $\begin{array}{c}3.09 \\
(1.66)\end{array}$ & & $1.42(0.37)$ & & $\begin{array}{c}1.48 \\
(0.29)\end{array}$ & & $\begin{array}{c}1.45 \\
(0.33)\end{array}$ & \\
\hline \multicolumn{9}{|l|}{ Family type } \\
\hline Nuclear family & $\begin{array}{l}3.18 \\
(1.71)\end{array}$ & \multirow{2}{*}{$2.130^{\star}$} & $1.43(0.38)$ & \multirow{2}{*}{0.051} & $\begin{array}{c}1.47 \\
(0.29)\end{array}$ & \multirow{2}{*}{-0.362} & $\begin{array}{c}1.44 \\
(0.33)\end{array}$ & \multirow{2}{*}{-0.205} \\
\hline Extended family & $\begin{array}{c}2.59 \\
(1.35)\end{array}$ & & $1.42(0.37)$ & & $\begin{array}{c}1.50 \\
(0.27)\end{array}$ & & $\begin{array}{c}1.45 \\
(0.29)\end{array}$ & \\
\hline \multicolumn{9}{|l|}{$\begin{array}{l}\text { Current } \\
\text { working status }\end{array}$} \\
\hline Yes & $\begin{array}{l}3.23 \\
(1.71)\end{array}$ & \multirow{2}{*}{$2.398^{\star}$} & $1.40(0.37)$ & \multirow{2}{*}{-1.609} & $\begin{array}{c}1.45 \\
(0.28)\end{array}$ & \multirow{2}{*}{$2.365^{\star}$} & $\begin{array}{c}1.41 \\
(0.32)\end{array}$ & \multirow{2}{*}{-1.902} \\
\hline No & $\begin{array}{l}2.59 \\
(1.41)\end{array}$ & & $1.50(0.39)$ & & $\begin{array}{c}1.57 \\
(0.28)\end{array}$ & & $\begin{array}{c}1.52 \\
(0.32)\end{array}$ & \\
\hline \multicolumn{9}{|l|}{ Car ownership } \\
\hline Yes & $\begin{array}{c}3.33 \\
(1.68)\end{array}$ & \multirow{2}{*}{$3.452^{\star}$} & $1.36(0.36)$ & \multirow{2}{*}{$-3.270^{\star}$} & $\begin{array}{c}1.43 \\
(0.26)\end{array}$ & \multirow{2}{*}{$3 . \overline{527^{\star}}$} & $\begin{array}{c}1.38 \\
(0.32)\end{array}$ & \multirow{2}{*}{$3.438^{*}$} \\
\hline No & $\begin{array}{c}2.44 \\
(1.43)\end{array}$ & & $1.57(0.37)$ & & $\begin{array}{c}1.60 \\
(0.30)\end{array}$ & & $\begin{array}{c}1.57 \\
(0.30)\end{array}$ & \\
\hline \multicolumn{9}{|l|}{ Smoking } \\
\hline Yes & $\begin{array}{c}2.94 \\
(1.59)\end{array}$ & - & $1.48(0.38)$ & \multirow{2}{*}{1.746} & $\begin{array}{c}1.50 \\
(0.30)\end{array}$ & \multirow{2}{*}{1.006} & $\begin{array}{c}1.49 \\
(0.33)\end{array}$ & \multirow{2}{*}{$2.119^{*}$} \\
\hline No & $\begin{array}{c}3.17 \\
(1.73)\end{array}$ & 0.856 & $1.37(0.36)$ & & $\begin{array}{c}1.45 \\
(0.27)\end{array}$ & & $\begin{array}{c}1.38 \\
(0.31)\end{array}$ & \\
\hline $\begin{array}{l}\text { Alcohol } \\
\text { consumer }\end{array}$ & & & & & & & & \\
\hline Yes & $\begin{array}{c}2.64 \\
(1.42)\end{array}$ & - & $1.59(0.38)$ & & $\begin{array}{c}1.56 \\
(0.31)\end{array}$ & & $\begin{array}{l}1.60 \\
(0.30)\end{array}$ & \\
\hline No & $\begin{array}{c}3.26 \\
(1.73) \\
\end{array}$ & $2.385^{\star}$ & $1.34(0.34)$ & $4.035^{\star}$ & $\begin{array}{c}1.44 \\
(0.26)\end{array}$ & $2.707^{\star}$ & $\begin{array}{l}1.36 \\
(0.31)\end{array}$ & $4.586^{\star}$ \\
\hline
\end{tabular}

Means, standard deviations, and independent sample $t$-tests $(\mathrm{t})$ of satisfaction with life and beck hopelessness sub-scales for age, marital status, family type, current working status, car ownership, smoking and alcohol use are presented in Table 4. A higher score indicates a higher frequency of use of beck hopelessness and satisfaction with life. Results generally show that participants who have higher scores about satisfaction with life reported to had a lower level of hopelessness or vice versa. 
Independent sample t-tests were conducted to assess the differences between two groups. There were significant differences for satisfaction with life $(t=2.070, p<0.05)$ feelings and expectations about the future $(t=-2.535, p<0.05)$, loss of motivation $(t=-$ 3.297, $p<0.05)$, whereas no difference for hope $(t=-1.409, p>0.05)$ use between age groups. On the other hand, significant differences were found between car ownership and satisfaction with life. Also there was significant difference between car ownership and all sub scales of hopelessness. Alcohol consumer participants had significant differences as sub-scale beck hopelessness and satisfaction with life. There was significant difference between satisfaction with life and family type. Disabled veterans live in a nuclear family had higher satisfaction with life scores.

The analysis of variance performed at $95 \%$ confidence for each dimension and ANOVA showed statistically significant differences between work unit and hope domain $(F(4,155)=3.54, p<.005)$. On the other hand, there was statistically significant difference between residence type and satisfaction with life $(F(4,155)=$ $3.01, \mathrm{p}<.005)$.

Table 5. Hierarchical multiple regression analysis of Satisfaction with Life as a moderator sub-dimension of Hopelessness

\begin{tabular}{|c|c|c|c|c|c|c|c|c|c|}
\hline & $B$ & Beta & $t$ & Sig. & $\boldsymbol{R}$ & $R^{2}$ & $\begin{array}{c}R^{2} \\
A d j .\end{array}$ & $\boldsymbol{F}$ & VIF \\
\hline Step 1 & & & & & .58 & .34 & .33 & $40.657^{\star \star}$ & \\
\hline $\begin{array}{l}\text { BHS Feelings and } \\
\text { expectations about the } \\
\text { future }\end{array}$ & -1.63 & -.371 & -3.458 & $.00^{* *}$ & & & & & 2.734 \\
\hline BHS Hope & -1.23 & -.245 & -2.282 & $.02^{*}$ & & & & & 2.734 \\
\hline Step 2 & & & & & .60 & .36 & .34 & $29.017^{* *}$ & \\
\hline $\begin{array}{l}\text { BHS Feelings and } \\
\text { expectations about the } \\
\text { future }\end{array}$ & -1.13 & -.259 & -2.164 & $.03^{*}$ & & & & & 3.472 \\
\hline BHS Hope & -.94 & -.189 & -1.717 & .08 & & & & & 2.921 \\
\hline BHS Loss of motivation & -1.18 & -.207 & -2.028 & $.04^{*}$ & & & & & 2.516 \\
\hline
\end{tabular}

${ }^{* \star} p<0,01,{ }^{*} p<0,05$

Hierarchical multiple regression analysis was utilized to explore the moderating role of loss of motivation in the relationship between feelings and expectations about the future, hope and satisfaction with life. Feelings and expectations about the future 
and hope was taken as an independent variable, satisfaction of life as a dependent variable, and loss of motivation as a moderating variable.

For step 1, feelings and expectations about the future and hope explained $34 \%$ of satisfaction of life result $\left(R=.58, R^{2}=.34, F=40.657, p<0.01\right)$. Variables of loss of motivation, which were included in the second step of the regression analysis, explained $36 \%$ of the total variance $\left(R=.60, R^{2}=.36, F=29.017, p<0.01\right)$. The standardized regression coefficients $(\beta)$ and t-test results concerning significance indicated a statistically significant relationship between feelings and expectations about the future $(\beta=-.25, p<0.05)$ and loss of motivation $(\beta=-.20, p<0.01)$ satisfaction of life and a non-significant relationship between hope $(\beta=-.18, p>0.05)$ and satisfaction of life.

\section{DISCUSSION}

This study took a broad approach to examine correlate of life satisfaction and hopelessness among the disabled veterans in the sample of Turkey. In general, several variables that disabled veterans have, played an important role in disabled veterans' current satisfaction with life and hopelessness. Several studies show that there is a significant relationship between socio-demographic, occupational traits and satisfaction with life and hopelessness (Tuncay \& Musabak, 2015; London, Heflin, \& Wilmoth, 2011; Matarazzo et al., 2014; Mroczek \& Spiro III, 2005; Seidl et al., 2015; Seligowski et al., 2012; Violanti et al., 2016).

The effects of life satisfaction and hopelessness on disabled veterans vary by age. It is considered that there exists a linear relationship between increasing age and increasing hopelessness level (Karataş, Karataş, \& Şenol, 1989). In a few studies conducted with disabled veterans in Turkey, no relation between age and quality of life are found (Başcıllar, 2017; Yazicioglu, Duyan, Karatas, \& Özgül, 2006). It was found that young people who had active services in the military and who had disabled veterans had higher levels of depression and hopelessness than the older disabled veterans (Green, Grace, Lindy, Glesser, \& Leonard, 1999; Hankin, Spiro III, Miller, \& Kazis, 1999). According to findings of our research, there was a significant relationship between age and satisfaction with life. Disabled veterans who are below the age of 40 have higher satisfaction with life scores. And also there was a significant relationship between age and hopelessness. Disabled veterans who are above the age of 40 have higher hopelessness score. The main reason for this 
result can be seen as a change in the living standards after the disability. For an elderly veteran, adaptation to the new lifestyle may be seen as a more challenging process than younger veterans.

Başcıllar (2017) found a significant relationship between working status and quality of life. According to these findings, disabled veterans who have a job, had higher physical and mental dimension of quality of life scores. Supporting this, findings of our research showed that satisfaction with life is increasing when disabled veterans have a job. Working in a job can provide both a material welfare and the development of social interactions of individuals.

In terms of having a car, there were both physical and psychosocial reasons of buying a car for disabled veterans. Physically, in Turkey, as a disabled person, it is very hard to use public transportation. Especially in cities, crowded public buses and unfriendly environment conditions for disabled persons make harder to wonder around the city. Having an automobile designed according to the disability situation facilitates daily life of the disabled veterans. From psychosocial perspective having a property is also a part of the process that allow us to communicate non-verbally and to achieve the satisfaction of self-expression through consumption. So, there was a significant relationship between self and consumption. People express themselves through the congruence of self-images and images of owned or desired products(Belk, Bahn, \& Mayer, 1982, p. 4). Therefore, after the physical and psychosocial destruction, the possession of automobile as an attitude expressing themselves is an important result. In our study, there was a significant relationship between car ownership and satisfaction with life and hopelessness. Başcıllar (2017) found that there is a significant relationship between car ownership and social and environmental sub-scales of quality of life. According to our results, we understand that ownership of car makes life easier for disabled veterans and increase the satisfaction with life.

The current evidence about the relationship between alcohol consumption and life satisfaction is very limited. Levy, Bell, and Lin (1980) found a linear relationship between increasing alcohol consumption and increasing life satisfaction. But in our study in contrast to Levy et al. (1980) research, negative relationship is found between increasing alcohol consumption and decreasing life satisfaction. Alcohol use can be seen as an avoid responsibilities (Steinberg, Adams, Montemayor, \& Gullota, 1989). Also, the social acceptance of perpetual alcohol consumption in 
terms of Turkish society can be seen as limited. In this respect, the possibility of increasing the continuity of alcohol consumption may include the risk of exclusion by the society. Such a possibility might negatively affect the life satisfaction of disabled veterans.

The findings illustrate that disabled veterans who have lower hopelessness level correlated higher satisfaction with life. As shown in Table 4, satisfaction with life is explained by feelings and expectations about the future, hope and loss of motivation in Step 2 for disabled veterans samples beyond the prior controlled for Steps 1 variables. At the same time, hopelessness accounted for a significant amount of variance in disabled veterans' satisfaction with life. The results appear in Table 4 and reveal that the coefficient for hope dropped to non-significance in the second stage, loss of motivation mediates the relationship between hope and satisfaction with life; it is indicative of full mediation. In conclusion there is a strong correlation between satisfaction with life and hopelessness of disabled veterans. Each domain of hopelessness is correlated with satisfaction with life.

\section{Conclusion}

The aim of this study is to examine hopelessness and satisfaction with life of disabled veterans. In this context, the relationship between socio-demographic variables, hopelessness, its sub-dimensions and satisfaction with life for disabled veterans is evaluated.

Socio-demographic factors such as age, family type, working status, car ownership and using alcohol are found to be related to satisfaction with life. Car ownership and alcohol using are found to be related to all sub-scales of hopelessness.

Satisfaction with life, as the dependent variable of the study, in this sample is found to be related to hopelessness. That is, a change in the level of disabled veterans' hopelessness will affect their satisfaction with life. The results of our study suggest that there is a significant role for higher satisfaction with life in relation to lower levels of hopelessness in disabled veterans, and any change are likely to affect to disabled veterans. These are the strengths of our study.

However, there are also some limitations of this research. First, non-sampling method was used in this study. Therefore, it is not possible to generalize research findings to all disabled veterans in Turkey. Second, the sample of this research is 
small. Third, research questions were answered by self-report method. This method may cause self-report bias.

It is possible to examine further research recommendations in three basic categories. First, it is foreseen that the larger research group will increase the representation of the results. Second, qualitative research will allow for more indepth examination of the problem area. Third, funds provided by governmental organizations for the support of the research will allow more comprehensive research that examine disabled veterans in the psychosocial context.

\section{REFERENCES}

Başc1llar, M. (2017). Malul Terör Gazilerinin Sosyal Destek ve Yaşam Kalitesinin Değerlendirilmesi. (Yüksek Lisans Tezi), Hacettepe Üniversitesi Ankara.

Beck, A. T., Weissman, A., Lester, D., \& Trexler, L. (1974). The measurement of pessimism: the hopelessness scale. Journal of consulting and clinical psychology, 42(6), 861.

Belk, R. W., Bahn, K. D., \& Mayer, R. N. (1982). Developmental recognition of consumption symbolism. Journal of Consumer Research, 9(1), 4-17.

Blaney, N. T., Goodkin, K., Feaster, D., Morgan, R., Millon, C., Szapocznik, J., \& Eisdorfer, C. (1997). A psychosocial model of distress over time in early HIV-1 infection: The role of life stressors, social support and coping. Psychology and Health, 12(5), 633-653.

Büyüköztürk, Ş. (2013). Sosyal Bilimler için Veri Analizi El Kitabı İstatistik, Araştırma Deseni SPSS Uygulamaları ve Yorum (Genişletilmiş 18 ed.). Ankara: Pegem Yayıncılık.

Confederation of Turkish Trade Unions. (2018). Açlık ve Yoksulluk Sinırı. Retrieved from www.turkis.org.tr/dosya/qqEA08H3p12C.pdf

Diener, E., Emmons, R. A., Larsen, R. J., \& Griffin, S. (1985). The satisfaction with life scale. Journal of personality assessment, 49(1), 71-75.

Durak, A. (1994). Validity and reliability study of the Beck Hopelessness Scale. Turk Psikol Derg, 9 , $1-11$.

Foote, C. E., Mac Kinnon, J., Robbins, C., Pessagno, R., \& Portner, M. D. (2015). Long-term health and quality of life experiences of Vietnam veterans with combat-related limb loss. Quality of Life Research, 24(12), 2853-2861.

Green, B. L., Grace, M. C., Lindy, J. D., Glesser, G. C., \& Leonard, A. (1999). Risk factors for PTSD and other diagnose in general sample of Vietnam veterans. American journal of Psychiatry, 147, 729-733.

Hankin, C. S., Spiro III, A., Miller, D. R., \& Kazis, L. (1999). Mental disorders and mental health treatment among US Department of Veterans Affairs outpatients: the Veterans Health Study. American journal of Psychiatry, 156(12), 1924-1930. 
Karataş, S., Karataş, K., \& Şenol, C. (1989). Huzurevinde Kalan Yaşlıların Yaşam Doyum Düzeyleri ile Ölüm Kaygıları Arasındaki İlişki. XXV. Ulusal Psikiyatri ve Nörolojik Bilimler Kongresi, 675-677.

Kocalevent, R.-D., Finck, C., Pérez-Trujillo, M., Sautier, L., Zill, J., \& Hinz, A. (2016). Standardization of the Beck Hopelessness Scale in the general population. Journal of mental health, 1-7.

Köker, S. (1991). Normal ve sorunlu ergenlerin yaşam doyumu düzeylerinin karşılaştırılması. Yayınlanmamış Yüksek Lisans Tezi, Ankara Üniversitesi Sosyal Bilimler Enstitüsü, Ankara.

Levinson, D. J. (1978). The seasons of a man's life: Random House Digital, Inc.

Levy, A. B., Bell, R. A., \& Lin, E. (1980). Life satisfaction-Aspirations and alcohol use: A preliminary report. Social indicators research, 8(4), 441-452.

London, A. S., Heflin, C. M., \& Wilmoth, J. M. (2011). Work-related disability, veteran status, and poverty: Implications for family well-being. Journal of Poverty, 15(3), 330-349.

Matarazzo, B. B., Hoffberg, A. S., Clemans, T. A., Signoracci, G. M., Simpson, G. K., \& Brenner, L. A. (2014). Cross-cultural adaptation of the Window to Hope: A psychological intervention to reduce hopelessness among US Veterans with traumatic brain injury. Brain injury, 28(10), 1238-1247.

Melges, F. T., \& Bowlby, J. (1969). Types of hopelessness in psychopathological process. Archives of General Psychiatry, 20(6), 690-699.

Mroczek, D. K., \& Spiro III, A. (2005). Change in life satisfaction during adulthood: findings from the veterans affairs normative aging study. Journal of Personality and Social Psychology, $88(1), 189$.

Vazife Malullüklerinin Nevileri ile Dereceleri Hakkında Niamname, 1053 C.F.R. (1953).

Seber, G. (1991). Beck umutsuzluk ölçeğinin geçerlik ve güvenirliği üzerine bir çalışma. Yayınlanmamış doçentlik tezi. Anadolu Üniversitesi Tıp Fakültesi, Psikiyatri Bölümü, Eskişehir.

Seidl, J. N. T., Pastorek, N. J., Lillie, R., Rosenblatt, A., Troyanskaya, M., Miller, B. I., . . . Linck, J. (2015). Factors related to satisfaction with life in veterans with mild traumatic brain injury. Rehabilitation psychology, 60(4), 335.

Seligowski, A. V., Pless Kaiser, A., King, L. A., King, D. W., Potter, C., \& Spiro III, A. (2012). Correlates of life satisfaction among aging Veterans. Applied Psychology: Health and Well-Being, 4(3), 261-275.

Steinberg, L., Adams, G., Montemayor, R., \& Gullota, T. (1989). Advances in adolescent behavior and development. In: Newbury Park, CA: Sage Publications.

TBMM. (2012). 7/7338 Sayll Yazllı Soru Önergesi. Ankara: TBMM Retrieved from http://www2.tbmm.gov.tr/d24/7/7-7338sgc.pdf

Tuncay, T., \& Musabak, I. (2015). Problem-focused coping strategies predict posttraumatic growth in veterans with lower-limb amputations. Journal of Social Service Research, 41(4), 466-483.

Turkish Statistical Institute. (2018). Gelir Dağılımı ve Yaşam Koşulları İstatistikleri. 
U.S. Census Bureau. (2016). Facts for Features: Veteran's Day 2015: Nov. 11, 2016. Retrieved from https://factfinder.census.gov/faces/tableservices/jsf/pages/productview.xhtml?src=bkmk

Ural, A., \& Kılıç, İ. (2005). Bilimsel Araştırma Süreci ve SPSS ile Veri Analizi. Ankara: Detay Yayıncilik.

Vara, Ş. (1999). Yoğun bakım hemşirelerinde iş doyumu ve genel yaşam doyumu arasındaki ilişkilerin incelenmesi. Yayınlanmamış Yüksek Lisan Tezi, İzmir Ege Üniversitesi Sağlık Bilimleri Enstitüsü, İzmir.

Violanti, J. M., Andrew, M. E., Mnatsakanova, A., Hartley, T. A., Fekedulegn, D., \& Burchfiel, C. M. (2016). Correlates of hopelessness in the high suicide risk police occupation. Police Practice and Research, 17(5), 408-419.

Wu, L., \& Lewis, M. W. (2015). Disabilities among veterans and their utilization of health care. Health Psychology and Behavioral Medicine, 3(1), 296-314.

Yazicioglu, K., Duyan, V., Karatas, K., \& Özgül, A. (2006). Effects of sociodemographic characteristics, illness process, and social support on the levels of perceived quality of life in veterans. Military medicine, 171(11), 1083. 